\title{
Correlates of Married Men's Attitude towards Gender Based Violence, Secondary Analysis of Survey of Young People In Egypt (SYPE) Data, 2014.
}

\author{
Asmaa M. A. Soliman', Hala H. I. Abou Faddan', Taghreed A. M. Ismail ${ }^{1}$ \\ ${ }^{1}$ Department of Public Health and Community Medicine, Faculty of Medicine, Assiut \\ University, Assiut, Egypt.
}

Received: April, 2017 Accepted: June, 2017

\begin{abstract}
Background: Nowadays, One of the Main public health problems is intimate partner violence (IPV). Men's Attitude has been verified as one of the important predictors of IPV. Objectives: To Identify attitude and its correlates towards gender-based violence (GBV) among ever married males. Methods: Secondary analysis using Survey of Young People in Egypt (SYPE) data, 2014. Dependent variable: men's attitude towards gender-based violence. Independent variables: socio-demographic variables, attitude toward gender equity, parent's response to mistakes, mental health and some marital issues. Results: Among ever married males, $77.1 \%$ accepted GBV, $82.2 \%$ whom wives age at marriage was less than 18 years, $81.8 \%$ from rural residence, $88.4 \%$ whom parents were not giving any response to mistakes, $83.9 \%$ of those with positive attitude toward divorcing their wives accepted GBV with statistically significant difference. Logistic regression analysis revealed that the significant predictors for accepting GBV were: rural residence, attitude that makes husbands divorce their wives and parents' response to mistakes. Conclusion: The significant correlates of married men's acceptance of GBV were rural residence, respondents with an attitude toward divorcing their wives and inappropriate parents' response to mistakes. Recommendations: Development of intervention programs aiming to change social and cultural gender norms related to gender inequality and GBV especially in rural areas is highly recommended.
\end{abstract}

Key words: Attitudes; correlates, Men; Gender based violence.

Corresponding author : Asmaa Mohamed Ahmed Soliman Email: asmaasoliman74@yahoo.com

\section{Introduction}

Nowadays, One of the Main public health problems is violence against women mainly intimate partner violence (IPV) which is contravention of women's human rights. ${ }^{1}$ The public attitudes are an important issue in accepting men's violence against women. Social and cultural norms affect attitudes, and they are evidence of way of thinking about violence. ${ }^{2}$ Attitude toward IPV has been considered as one of the important predictors of practicing violence against women. ${ }^{3,4,5}$ Attitudes have an impact on early detection, reaction and acceptance of gender based violence(GBV) and degree of women support. ${ }^{2}$ Men's attitudes are fundamental to liability and responsibility for violence because most of violence against women is carried out by men. ${ }^{6}$ Recently , about 1 in $3(35 \%)$ of women worldwide are 
exposed to physical and spousal violence in their life. 1,7 Violence harmfully influence women's physical, mental, sexual and reproductive health, and might raise susceptibility to HIV. ${ }^{1}$ Poor education, child abuse, use of alcohol, attitudes accepting of violence and gender inequity are important correlates of IPV. ${ }^{1}$ It is proofed that school-based programs are efficient to decrease spousal violence especially among adolescent and youth. ${ }^{1}$ Generally, men's attitudes toward spousal violence are varying between different countries. ${ }^{8,9,10}$ Consistent with demographic and Health Survey (DHS) data, 2004 in Sub-Saharan Africa, the percentage of males who accepted partner violence vary from $25 \%$ in Malawi to $75 \%$ in Ethiopia. ${ }^{9}$ In South Asia, men's acceptance of IPV is $29 \%$ in Nepal and $57 \%$ in India. ${ }^{10}$ Regarding GBV in Egypt, according to the Demographic Household Survey, 2008 and other studies; there was a significant increase in all types of violence in latest years in spite of under-reporting. Recent Egyptian statistics, 2014 revealed that $36 \%$ of ever-married women aged between (1549) have exposed to physical violence since the age of 15 . Majority of victims (64\%) reported that their current husbands are the performers, but parents are also often reported (father/ step-father, 26\%, mother/ step mother, $31 \%) .{ }^{11}$

In Egypt, while many studies were describing the exposure to violence, still there is no available data describing the attitude of men towards violence against women. The objectives of our study were to identify attitude towards GBV among ever married males and its correlates.
Objectives To identify attitude towards GBV among ever married males and To identify correlates of men's attitude towards GBV among ever married males.

\section{Methods:}

Secondary analysis: Using SYPE data, 2014 to analyze attitude towards genderbased violence among ever married males and its correlates. This data was collected by the Population Council. It was the second round of data for the (SYPE) in 2013/2014, which re-interviewed the same sample of young people that were interviewed in 2009. SYPE 2009 interviewed a nationally representative sample of 15,029 young people aged 10-29 from 11,372 households. SYPE 2014 managed to interview $10,916(72.6 \%)$ of those same young people (now aged 1335) who were interviewed in SYPE 2009. All ever married men in SYPE data (2014) were included in the secondary analysis of our study and they were 1367 .

The data set was available to the researchers by Population Council. The Population Council arranged training course for the researchers about how to manipulate the data and identify the variables.

Inclusion criteria: Ever married men. Dependent variables: Men's attitude towards gender-based violence (Q 4145). Independent variables: Independent variables: sixteen variables were selected including 1- Socio-demographic variables (age, residence (urban), respondent's education (educ2), employment status (empsts), wealth quintile (wiq_W), smoking status(Q7207) and wife age at marriage(Q4108_D) ). Some of these variables were recoded. 2- Some family/marital issues: Family type (Q4131), consanguinity (Q4118), marital 
relation (Q4121), marital happiness (Q4122) and husband wife communications (Q4120). 3- Mental distress (Q4227- 4246). 4- Attitude toward gender equity (Q4140). 5-Attitude to accept wife's right to ask for divorce (Q4142) 6- Attitude toward wife divorce (Q4143). 7- Parents response to mistakes (4249).

Note: some of the titles of these variables were recruited from SYPE questionnaires and others from SPSS data files sent by the population council.

Data manipulation: included (a) Determining available dependent \& independent variables. (b) Cleaning of the different variables. (c) Scoring and recoding of the variables. (d) Statistical analysis

Steps of constructing indices (scores from many variables): (1) Choosing variables for constructing each index. (2) Applying reliability analysis (Cronbach's Alpha) to the chosen variables. (3) Recoding and computing variables. (4) Classifying each index to grades: Low: $\leq 25 \%$, Middle: $>25-\leq 75 \%$, High: $>75 \%$

Analysis plan: The Statistical Package for Social Science (SPSS) version 16 was used for data management. Univariate analysis was done in the form of frequency tables, bivariate analysis (cross tables) \&multivariate analysis (logistic regression). Chi-square was used for bivariate analysis. Probability level (P value $)<0.05$ considered significant. logistic regression was applied for significant variables.

\section{Ethical consideration}

Ethical approval was obtained from Population Council for manipulation of SYPE data, secondary analysis and publication of scientific paper.

\section{Results}

Table (1): $\quad$ Socio-demographic characteristics of ever married males SYPE, 2014.

\begin{tabular}{|c|c|c|}
\hline Characteristics & $\begin{array}{c}\mathrm{N} \\
(\mathrm{N}=1367)\end{array}$ & $\%$ \\
\hline \multicolumn{3}{|l|}{ Age groups: } \\
\hline - $18-24$ & 156 & 11.4 \\
\hline - $25-29$ & 560 & 41.0 \\
\hline - $30-35$ & 651 & 47.6 \\
\hline$($ Mean \pm SD $)$ & \multicolumn{2}{|c|}{$29.0 \pm 3.4$} \\
\hline \multicolumn{3}{|l|}{ Wife age at marriage } \\
\hline - <18 years & 236 & 17.3 \\
\hline - $\geq 18$ years & 1131 & 82.7 \\
\hline$($ Mean \pm SD $)$ & \multicolumn{2}{|c|}{$20.6 \pm 3.9$} \\
\hline \multicolumn{3}{|l|}{ Urban-rural residence } \\
\hline - Urban & 519 & 38.0 \\
\hline - Rural & 848 & 62.0 \\
\hline \multicolumn{3}{|l|}{ Place of residence } \\
\hline - Urban governorates & 247 & 18.1 \\
\hline - Urban Lower Egypt & 138 & 10.1 \\
\hline - Rural Lower Egypt & 505 & 36.9 \\
\hline - Urban Upper Egypt & 72 & 5.3 \\
\hline - Rural Upper Egypt & 269 & 19.7 \\
\hline - Frontier Governorates & 136 & 9.9 \\
\hline \multicolumn{3}{|l|}{ Respondent's education: } \\
\hline - illiterate & 122 & 8.9 \\
\hline - basic education* & 316 & 23.1 \\
\hline - secondary education & 630 & 46.1 \\
\hline - university and above & 299 & 21.9 \\
\hline \multicolumn{3}{|l|}{ Employment status: } \\
\hline - Employed & 1269 & 92.8 \\
\hline - Un-employed** & 98 & 7.2 \\
\hline \multicolumn{3}{|l|}{ Wealth quintile: } \\
\hline - Lowest & 225 & 16.5 \\
\hline - Second & 257 & 18.8 \\
\hline - Middle & 293 & 21.4 \\
\hline - Fourth & 313 & 22.9 \\
\hline - Richest & 279 & 20.4 \\
\hline \multicolumn{3}{|l|}{ Family type: } \\
\hline - extended family & 419 & 30.7 \\
\hline - nuclear family & 948 & 69.3 \\
\hline \multicolumn{3}{|l|}{ Smoking status: } \\
\hline - Never smoke & 748 & 54.7 \\
\hline - Current smoker & 592 & 43.3 \\
\hline - Ex-smoker & 27 & 2.0 \\
\hline \multicolumn{3}{|c|}{$\begin{array}{l}\text { N.B: *Basic education include primary and } \\
\text { preparatory education, **Unemployed include } \\
\text { those not currently working and those out of labor } \\
\text { force. }\end{array}$} \\
\hline
\end{tabular}

Table (1) shows the socio-demographic characteristics of the study population. A total 1367 of ever married men were 
Table (2): Attitude towards gender-based violence among ever married males by sociodemographic characteristics, SYPE, 2014.

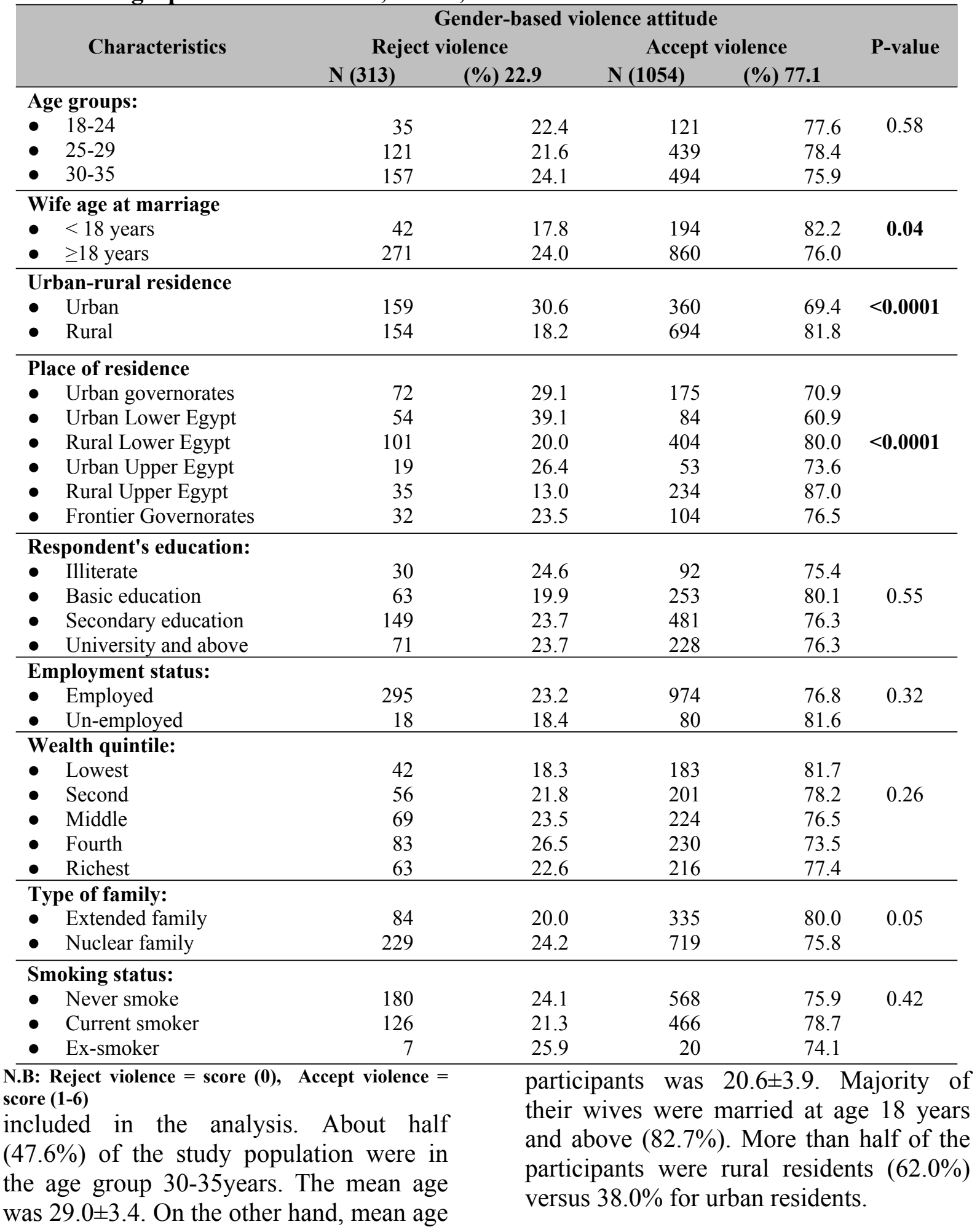

of wives at marriage of the study

\begin{tabular}{lllll}
\hline The Egyptian Journal of Community Medicine & Vol. 36 & No. 2 & April & 2018
\end{tabular} 
Table (3): Attitude of ever married males towards gender-based violence by Parent's response to Mistakes, Mental Distress \& some marital issues, SYPE, 2014.

\begin{tabular}{|c|c|c|c|c|c|}
\hline \multirow{3}{*}{ Characteristics } & \multicolumn{4}{|c|}{ Gender-based violence attitude } & \multirow{3}{*}{ P-value } \\
\hline & \multicolumn{2}{|c|}{ Reject violence } & \multicolumn{2}{|c|}{ Accept violence } & \\
\hline & $\mathbf{N}$ & $(\%)$ & $\mathbf{N}$ & $(\%)$ & \\
\hline $\begin{array}{l}\text { Parent's response to Mistakes: } \\
\text { - Explain quietly } \\
\text { - Emotional violence } \\
\text { - Physical violence } \\
\text { - Nothing } \\
\text { - Total* }\end{array}$ & $\begin{array}{r}111 \\
92 \\
99 \\
10 \\
312 \\
\end{array}$ & $\begin{array}{l}24.7 \\
20.5 \\
26.8 \\
11.6 \\
23.1\end{array}$ & $\begin{array}{r}338 \\
356 \\
271 \\
76 \\
1041 \\
\end{array}$ & $\begin{array}{l}75.3 \\
79.5 \\
73.2 \\
88.4 \\
76.9\end{array}$ & 0.009 \\
\hline $\begin{array}{l}\text { Mental health score }{ }^{* *} \text { : } \\
\text { - Normal score } \\
\text { - Mental distress } \\
\text { - Total }\end{array}$ & $\begin{array}{r}301 \\
12 \\
313 \\
\end{array}$ & $\begin{array}{l}22.9 \\
22.2 \\
22.9 \\
\end{array}$ & $\begin{array}{r}1012 \\
42 \\
1054 \\
\end{array}$ & $\begin{array}{l}77.1 \\
77.8 \\
77.1 \\
\end{array}$ & 0.71 \\
\hline $\begin{array}{l}\text { Attitude toward gender equity: } \\
\text { - Low }(<25) \\
\text { - Middle }(26-31) \\
\text { - High }(>32) \\
\text { - Total }\end{array}$ & $\begin{array}{r}65 \\
161 \\
87 \\
313 \\
\end{array}$ & $\begin{array}{l}18.7 \\
23.3 \\
26.4 \\
22.9\end{array}$ & $\begin{array}{r}283 \\
529 \\
242 \\
1054 \\
\end{array}$ & $\begin{array}{l}81.3 \\
76.7 \\
73.6 \\
77.1\end{array}$ & 0.05 \\
\hline $\begin{array}{l}\text { Consanguinity: } \\
\text { - First cousin } \\
\text { - Others } \\
\text { - No } \\
\text { - Total }\end{array}$ & $\begin{array}{r}28 \\
47 \\
238 \\
313 \\
\end{array}$ & $\begin{array}{l}17.3 \\
24.4 \\
23.5 \\
22.9\end{array}$ & $\begin{array}{r}134 \\
146 \\
774 \\
1054 \\
\end{array}$ & $\begin{array}{l}82.7 \\
75.6 \\
76.5 \\
77.1\end{array}$ & 0.18 \\
\hline $\begin{array}{l}\text { Marital happiness: } \\
\text { - Very happy/Happy } \\
\text { - Does not matter } \\
\text { - Unhappy } \\
\text { - Total* }\end{array}$ & $\begin{array}{r}289 \\
15 \\
7 \\
311 \\
\end{array}$ & $\begin{array}{l}23.7 \\
14.0 \\
26.9 \\
23.0\end{array}$ & $\begin{array}{r}932 \\
92 \\
19 \\
1043 \\
\end{array}$ & $\begin{array}{l}76.3 \\
86.0 \\
73.1 \\
77.0\end{array}$ & 0.07 \\
\hline $\begin{array}{l}\text { Marital Relation***: } \\
\text { - low score }(<20) \\
\text { - middle score }(21-25) \\
\text { - high score }(>26) \\
\text { - Total } * \\
\end{array}$ & $\begin{array}{r}65 \\
186 \\
60 \\
311 \\
\end{array}$ & $\begin{array}{l}25.1 \\
25.4 \\
16.6 \\
23.0\end{array}$ & $\begin{array}{r}194 \\
547 \\
302 \\
1043 \\
\end{array}$ & $\begin{array}{l}74.9 \\
74.6 \\
83.4 \\
77.0 \\
\end{array}$ & 0.003 \\
\hline $\begin{array}{l}\text { Husband wife communications } \\
\text { - Rarely }(<8) \\
\text { - Often }(9-11) \\
\text { - Always }(>12) \\
\text { - Total* }\end{array}$ & $\begin{array}{r}58 \\
176 \\
77 \\
311\end{array}$ & $\begin{array}{l}19.4 \\
24.2 \\
23.5 \\
23.0\end{array}$ & $\begin{array}{r}41 \\
551 \\
251 \\
1043\end{array}$ & $\begin{array}{l}80.6 \\
75.8 \\
76.5 \\
77.0\end{array}$ & 0.24 \\
\hline $\begin{array}{l}\text { Score of attitude to accept wife's right } \\
\text { to ask for divorce: } \\
\text { - Low agreement }(<3) \\
\text { - Middle agreement }(4-7) \\
\text { - High agreement }(>8) \\
\text { - Total* }\end{array}$ & $\begin{array}{r}60 \\
155 \\
71 \\
286\end{array}$ & $\begin{array}{l}21.2 \\
22.7 \\
21.2 \\
22.0\end{array}$ & $\begin{array}{r}223 \\
527 \\
264 \\
1014\end{array}$ & $\begin{array}{l}78.8 \\
77.3 \\
78.8 \\
78.0\end{array}$ & 0.12 \\
\hline $\begin{array}{l}\text { Score of attitude toward wife divorce: } \\
\text { - Low agreement }(<3) \\
\text { - Middle agreement }(4-6) \\
\text { - High agreement }(>7) \\
\text { - Total }\end{array}$ & $\begin{array}{r}137 \\
127 \\
49 \\
313\end{array}$ & $\begin{array}{l}30.1 \\
20.9 \\
16.1 \\
22.9\end{array}$ & $\begin{array}{r}318 \\
481 \\
255 \\
1054\end{array}$ & $\begin{array}{l}69.9 \\
79.1 \\
83.9 \\
77.1\end{array}$ & $<0.0001$ \\
\hline
\end{tabular}

\begin{tabular}{lllll}
\hline The Egyptian Journal of Community Medicine & Vol. 36 & No. 2 & April & 2018
\end{tabular}


Table (4): Multivariate analysis of factors affecting attitude of ever married males towards gender-based violence, SYPE, 2014.

\begin{tabular}{lcrrrrrrrr} 
& & & & & & \multicolumn{3}{c}{$\begin{array}{c}\text { 95\% C.I. for EXP } \\
\text { (B) }\end{array}$} \\
\cline { 6 - 10 } & \multicolumn{1}{c}{ B } & S.E. & Wald & df & Sig. & Exp(B) & Lower & Upper \\
\hline Marital relation & .039 & .020 & 3.907 & 1 & .05 & 1.040 & 1.000 & 1.080 \\
\hline Attitude toward wife divorce & .162 & .029 & 30.634 & 1 & .000 & 1.176 & 1.110 & 1.245 \\
\hline Rural residence & .618 & .135 & 21.083 & 1 & .000 & 1.855 & 1.425 & 2.414 \\
\hline Wife age & $-.300-$ & .190 & 2.486 & 1 & .12 & .741 & .510 & 1.076 \\
\hline Parents' response to mistakes & .080 & .039 & 4.125 & 1 & .04 & 1.083 & 1.003 & 1.169 \\
\hline Constant & $-1.019-$ & .645 & 2.496 & 1 & .11 & .361 & & \\
\hline
\end{tabular}

The highest percentage of the participants were from rural lower Egypt (36.9\%). Regarding the educational status, $46.1 \%$ of the participants had secondary education. The majority of all participants were employed (92.8\%). Nearly one fifth of each study population was distributed in each class of the wealth quintile. More than two thirds $(69.3 \%)$ were living in nuclear family while $43.3 \%$ of studied men were current smoker.

Fig. (1) shows that $77.1 \%$ of study population were accepting attitude toward GBV versus $22.9 \%$ who were rejecting GBV.

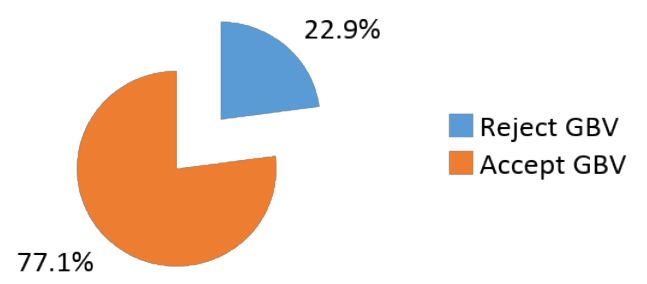

Fig. (1): Attitude of ever married men toward GBV, SYPE, 2014

Table (2) shows the relationship between attitudes of ever married males towards gender-based violence and sociodemographic characteristics. There was no statistical significant difference between the participants in different age groups regarding GBV. Most of men (82.2\%) whom wives age at marriage were less than 18 years were accepting GBV versus $76.0 \%$ in the other group with statistical significant difference. Majority of participants from rural residence $(81.8 \%)$ were accepting GBV participants versus $69.4 \%$ urban residents with high statistical significant difference. Neither educational level nor the wealth quintile of the study participants was a statistically significant factor in attitude toward GBV. Higher percent of men (81.6\%) who were unemployed were accepting GBV. Also $80 \%$ of those who were living in extended families were accepting GBV with no statistical significant difference. There was no statistical significant difference among the study participants in attitude toward GBV according to the smoking status.

Fig. (2) shows that rural residents were more accepting GBV than urban residents with high statistical significant difference $(\mathrm{p}<0.0001)$.

Table (3) shows that the majority of participants $(88.4 \%)$ whom parents were not giving any response to mistakes were accepting GBV with significant statistical difference. Neither mental health score of the participants nor consanguinity was statistically significant regarding GBV. Most of participants with low attitude toward gender equity $(81.3 \%)$ were accepting GBV with no statistical insignificant difference. Regarding marital happiness; (either happy, doesn't matter or unhappy as described by the participants themselves) and also the state of husband wife communication (either occurring rarely, often or always) showed no statistical significant difference regarding 


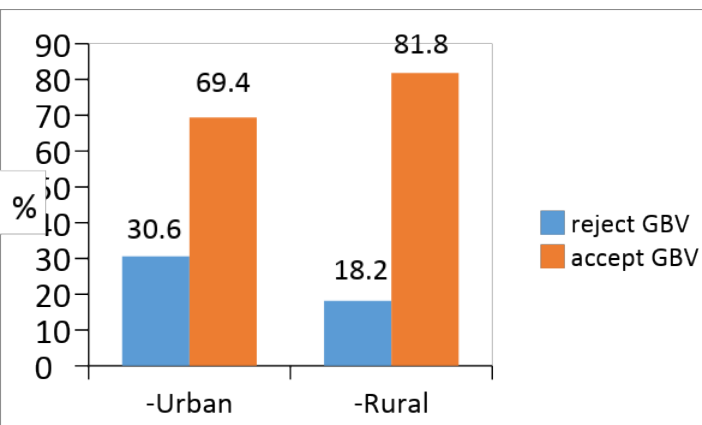

Fig. (2): Distribution of the attitude of ever married men toward GBV according to residence, SYPE,2014.

GBV attitude. Participants who had high score of good marital relations items showed the highest percent of acceptance of GBV (83.4\%) with high statistical significant difference. The majority of participants $(83.9 \%)$ of high agreement toward divorcing their wives were accepting GBV with high statistical significant difference. On the other hand, the score of attitude of the participants to accept wife's right to ask for divorce showed no statistical significant difference regarding attitude toward GBV.

\section{Multivariate analysis:}

logistic regression was done (Table 4) and revealed that the significant predictors for accepting GBV were: rural residence, respondent's high attitude toward wife divorce and parents response to mistakes.

\section{Discussion:}

for successful prevention policy, an understanding of attitudes toward GBV is fundamental. ${ }^{12}$ Researches concealed that different issues shaping attitude toward GBV were complex. ${ }^{13}$

Acceptance of GBV: Acceptance of GBV was varying between countries, higher in developing than developed countries. ${ }^{14}$ The present study revealed that $77.1 \%$ of the studied men were accepting GBV, which is consistent with findings of other studies; In Kenya $(62 \%)^{15}$, and In Ethiopia $(85 \%)^{16}$, In rural Uganda, $70 \%$ of men justified violence $^{17}$, and $53 \%$ in Zimbabwe. ${ }^{18}$ In Jordan, Khawaja et al., $2008^{19}$ found that $60.1 \%$ of men in Palestinian refugee camps accepted violence. This finding may reflect the same cultures and believes among developing as African/Arab countries. On the other hand, other studies found that the percentage of accepting violence was $42 \%$ in Bangladesh, $51 \%$ in India, and $28 \%$ in Nepal. ${ }^{20}$ Other developed countries showed much lower rates e.g. in Moscow the rate ranged from $0.8 \%$ to $18.6 \%{ }^{21}$ Comparing acceptance of GBV among countries and context is not easy because respondents don't like to explore their actual attitudes, which is reflected on their responses. ${ }^{14}$

Residence: The present study showed that rural residence was important correlate of accepting violence $(81.8 \%$ rural versus $69.4 \%$ urban). This is conformed to findings from many studies. ${ }^{18,20,22,23}$ In addition, urbanization was associated with higher rejection of GBV. ${ }^{15}$ Deeply rooted rural cultures and believes support the tendency toward gender inequality and accepting violence.

Education: In the present study respondents with basic education were more accepting GBV with no statistical significant difference. Secondary analysis of nationally representative sample data of male adolescents in India, Bangladesh, and Nepal revealed that higher rate of acceptance of GBV among illiterate and primary educated respondents than secondary \& higher education. ${ }^{20}$ The same results were also reported by Uthman et al. $2009^{15}$ in all subsaharan countries except Liberia, Madagascar, and Nigeria.

Occupation: The results showed that unemployed men were more accepting GBV. On the other hand, Uthman et al., $2009^{15}$ reported that relationship between occupation and acceptance of GBV was mixed; respondents not in working force 
from Burkina Faso, Mozambique and Rwanda were higher in accepting GBV while currently not working respondents from Benin, Liberia, Madagascar, Malawi, Tanzania, and Zimbabwe were less accepting GBV.

Wealth quintile: The present study revealed that acceptance of GBV was more in lower wealth quintiles. High socio-economic status was reported as a factor of rejecting IPV by. ${ }^{15,19,20,22}$

Gender equity: Gender inequality was positively connected with acceptance of GBV. This agree with many other studies e.g. $6,24,25,26,27.28,29,30$ Study was done in India and Japan revealed that the variation in attitudes toward GBV was due to differences in attitude about gender roles and inequity and male domination. ${ }^{12,31,32}$ This finding may be due to support of the Egyptian culture to male dominance. However, Violence supporting attitude doesn't exist from neither simply being a man, nor from the personal characteristics of the person (age, education, occupation and socio-economic factors) but violence supportive attitude results mainly from low support of gender equality between men and women. ${ }^{6}$

Parent's response to mistakes: The current study showed that $88.4 \%$ of participants whom parents were not giving any response to mistakes accepted GBV with significant statistical difference. This finding highlights the important role of the family in the form of proper shaping men's attitude toward GBV. On the other hand another study was done in Cyprus among adolescents (18-25 years old) revealed that exposure to violence from their parents response to mistakes. Neither educational level nor the wealth quintile of the study participants was a statistically significant factor in attitude toward GBV. Neither mental score of the participants nor was important reason of violence against women. ${ }^{33}$

Mental health: The present study illustrated that $79.2 \%$ of mentally distressed participants accept violence. And this agree with a study done in Estonia which illustrated that one of significant individual reasons of GBV was mental health problems (e.g. depression) and tendency to aggression. ${ }^{33}$

Marital relations: Participants who had good marital relations showed the highest percent of accepting GBV (83.4\%) with high statistical significant difference. This finding could be explained by marital relation in the form of more freedom and uncontrolled discussion without rules may result in more marital problems due to useless argument and debate. Nazar\& Kouzekani 2007 revealed that marital problems are among the factors of accepting GBV. ${ }^{33}$

Limitations of the study: Missing data and the weight variable was not available.

\section{Conclusion}

and

\section{Recommendation:}

From Secondary analysis of SYPE data, 2014 we can conclude the following:

Most of men whom wives age at marriage were less than 18 years, from rural residence, whom parents were not giving any response to mistakes and who have high attitude toward divorcing their wives showed more acceptance of GBV. The significant independent factors associated with married men's acceptance of GBV were rural residence, respondent's high attitude toward wife divorce and parents'

consanguinity was statistically significant regarding GBV.

Based on the study results, the following are recommended:

Development of interventions and programs that give priority to improving 
men's attitudes towards GBV, aiming to change social and cultural gender norms related to gender inequality and GBV especially in rural areas through (1) Enforcing the role of religious and community leaders. (2) Comprehensive media awareness campaigns, workshops, seminars about GBV. (3) Developing and implementing school-based programs to correct the concepts and correct the acceptance of GBV. (4) Implementing parent counseling programs for proper child rearing practices. (5) Promoting attainment of secondary level education of boys and girls. (6) Taking strict actions to activate the legislation of age of marriage. (7) Activation of the premarital counseling. (8) Further studies for understanding the socio-cultural background that shapes men's attitude toward GBV and gender inequity are crucial for effective prevention strategies.

\section{References:}

1. WHO | Violence against women. World Health Organization; [cited 2016 Nov 28]; Available from: http://www.who.int/ mediacentre/factsheets/fs239/en/

2. Cox P. Violence against women: Additional analysis of the Australian Bureau of Statistics' Personal Safety Survey, 2012. 2015.

3. Wang L. Factors influencing attitude toward intimate partner violence. Aggress Violent Behav. 2016;29:72-8.

4. Gage AJ, Hutchinson PL. Power, control, and intimate partner sexual violence in Haiti. Arch Sex Behav. 2006;35(1):11-24.

5. Jewkes R, Levin J, Penn-Kekana L. Risk factors for domestic violence: Findings from a South African crosssectional study. Soc Sci Med. 2002;55(9):1603-17.

6. Ribbon W. Women 's Safety is a Men' $\mathrm{s}$ Issue $\square$ : Men' $\mathrm{s}$ attitudes to violence against women and what that means for men. 2014;(1):1-12.

7. World Health Organization. Global and regional estimates of violence against women: prevalence and health effects of intimate partner violence and non-partner sexual violence. 2013. 2013;57.

8. Antai DE, Antai JB. Attitudes of women toward intimate partner violence: a study of rural women in Nigeria. Rural Remote Health. 2008;8(3):996.

9. Rani M, Bonu S, Diop-Sidibe N. An empirical investigation of attitudes towards wife-beating among men and women in seven sub-Saharan African countries. Afr J Reprod Health. 2004;8(3):116-36.

10. Rani M, Bonu S. Attitudes toward wife beating: a cross-country study in Asia. J Interpers Violence. 2009;24(8):1371-97.

11. UNFPA Egypt | Gender-based violence [Internet]. [cited 2016 Nov 28]. Available from: http://egypt.unfpa.org/ topics/gender-based-violence-1

12. Nayak MB, Byrne CA, Martin MK, Abraham AG. Attitudes Toward Violence against Women: A Cross-Nation Study. Sex Roles. 2003;49(7-8):333-42.

13. Flood M, Pease B. Factors influencing attitudes to violence against women. Trauma Violence Abuse [Internet]. 2009 Apr 1 [cited 2016 Nov 28];10(2):125-42. Available from: http://tva.sagepub.com /content/10/2/125.abstract

14. Hester M. Future Trends and Developments: Violence Against Women in Europe and East Asia. Violence Against Women [Internet]. 2004 [cited 2016 Nov 28];10 (12). Available from: http://research-

information.bristol.ac.uk/en/publications/f uture-trends-and-developments-violenceagainst-women-in-europe-and-eastasia(7e22a902-fd65-4ad2-ac10-

06a8e65f4361)/export.html

15. Uthman OA, Lawoko S, Moradi T. 
Factors associated with attitudes towards intimate partner violence against women: a comparative analysis of 17 sub-Saharan countries. BMC Int Health Hum Rights [Internet]. 2009;9(1):14. Available from: http://bmcinthealthhumrights.biomedcentra 1.com/articles/10.1186/1472-698X-9-14 16. Deyessa N, Berhane Y, Ellsberg M, Emmelin M, Kullgren G, Högberg U. Violence against women in relation to literacy and area of residence in Ethiopia. Glob Health Action [Internet]. 2010 Feb 25 [cited 2016 Nov 28];3. Available from: http://www.pubmedcentral.nih.gov/articler ender.fcgi?artid=2830802\&tool=pmcentre z\&rendertype $=$ abstract

17. Koenig MA, Lutalo $\mathrm{T}$, Zhao $\mathrm{F}$, Nalugoda F, Wabwire-Mangen F, Kiwanuka N, et al. Domestic violence in rural Uganda: Evidence from a community-based study. Bull World Health Organ. 2003;81(1):53-60.

18. Hindin MJ. Understanding women's attitudes towards wife beating in Zimbabwe. Bull World Health Organ. 2003;81(7):501-8.

19. Khawaja M, Linos N, El-Roueiheb Z. Attitudes of men and women towards wife beating: Findings from palestinian refugee camps in Jordan. J Fam Violence. 2008;23(3):211-8.

20. Dalal K, Lee MS, Gifford M. Male adolescents' attitudes toward wife beating: A multi-country study in South Asia. J Adolesc Heal. 2012;50(5):437-42.

21. Stickley A, Kislitsyna O, Timofeeva I, Vågerö D. Attitudes toward intimate partner violence against women in Moscow, Russia. J Fam Violence. 2008;23(6):447-56.

22. Waltermaurer E, Butsashvili M, Avaliani N, Samuels S, McNutt L-A. An examination of domestic partner violence and its justification in the Republic of Georgia. BMC Womens Health [Internet]. 2013;13(1):44. Available from: http://www.

scopus.com/inward/ record.url? eid=2-s2.0-84887594355 \&partnerID $=$ tZOtx3y 1

23. Antai D, Antai J. Collective violence and attitudes of women toward intimate partner violence: Evidence from the Niger Delta. BMC Int Health Hum Rights. 2009;9:12.

24. Lundgren R, Amin A. Addressing intimate partner violence and sexual violence among adolescents: Emerging evidence of effectiveness. Vol. 56, Journal of Adolescent Health. 2015. p. S42-50.

25. Yoshihama M, Blazevski J, Bybee D. Enculturation and Attitudes Toward Intimate Partner Violence and Gender Roles in an Asian Indian Population: Implications for Community-Based Prevention. Am J Community Psychol. 2014;53(3-4):249-60.

26. McDermott RC, Lopez FG. College Men's Intimate Partner Violence Attitudes: Contributions of Adult Attachment and Gender Role Stress. J Couns Psychol. 2012;60(1):127-36.

27. Yount KM, Halim N, Hynes M, Hillman ER. Response effects to attitudinal questions about domestic violence against women: A comparative perspective. Soc Sci Res. 2011;40(3):87384.

28. Boyle MH, Georgiades K, Cullen J, Racine Y. Community influences on intimate partner violence in India: Women's education, attitudes towards mistreatment and standards of living. Soc Sci Med. 2009;69(5):691-7.

29. Archer J. Cross-cultural differences in physical aggression between partners: a social-role analysis. Pers Soc Psychol Rev [Internet]. 2006;10(2):133-53. Available from: $\quad$ http://psr.sagepub.com/cgi/ doi/10.1207/s15327957pspr1002_3

30. Gage AJ. Women's experience of intimate partner violence in Haiti. Soc Sci Med. 2005;61(2):343-64. 
31. Campbell JC. Prevention of wife battering: Insights from cultural analysis. Response to Victim Women Child Vol 14(3)[Issue 80] 1992, 18-24. 1992;

32. Kozu J. Domestic Violence in Japan. Am Psychol [Internet]. 1999;54(1):50. Available from: http://search.ebscohost.com/login.aspx?dir ect $=$ true $\& d b=$ aph \&AN=1569559\&site $=$ eh ost-live 33. Nazar F, Kouzekani K. Attitudes towards Violence against Women in Kuwait. Vol. 61, Middle East Journal. 2007. 641-654 p.

34. Roushdy R, Maia Sieverding. Panel survey of young people in Egypt 2014: Generating evidence for policy, programs, and research. 2015; 